\title{
Doświadczanie przeszłości. Nekroperformans Doroty Sajewskiej
}

Ewa Guderian-Czaplińska

TEKSTY DRUGIE 2018, NR 4, S. 200-209

DOI: $10.18318 /$ td.2018.4.12

Na okładce książki widnieje fragment ludzkiej czaszki z kilkoma zębami zachowanymi w kości, a czaszka tkwi pod czyjąś pachą, niefrasobliwie tam wetknięta, trzymana jak arbuz albo piłka. Nie wiemy, pod czyją pachą, bo okładka „ucięła" resztę tej osoby; widać tylko nieco przymarszczony przy mankiecie rękaw białej koszuli i fragment torsu. Drugą połową ciała osoba w koszuli zajęła również tylną stronę okładki i po odwróceniu książki widać, że pod prawą pachą trzyma drugą czaszkę. Symetrycznie. Czaszki się różnią, w tej prawej zachowała się żuchwa, lewa straszy tylko resztkami zębów górnej szczęki. Na przodzie okładki nadrukowany jest niewielkimi literami - sam tytuł, Nekroperformans, nazwisko autorki odkrywamy dopiero po otwarciu książki, na stronie tytułowej (lub na grzbiecie, jeśli ktoś tam zerknie), gdzie już czytamy: Dorota Sajewska, Nekroperformans. Kulturowa rekonstrukcja teatru Wielkiej Wojny. Zaś zaraz po stronie tytułowej, z nietypowo umieszczonym na lewej karcie spisem treści, mamy wydruk całej fotografii z okładki. Tym razem widnieje na niej cała postać. Młody mężczyzna

\author{
Ewa Guderian- \\ -Czaplińska - prof. \\ UAM. Pracuje w Insty- \\ tucie Teatru i Sztuki \\ Mediów UAM w Po- \\ znaniu. Autorka prac \\ o dramaturgii polskiej \\ awangardy (Szara \\ strefa awangardy), \\ życiu teatralnym \\ w dwudziestoleciu \\ międzywojennym \\ (Teatralna Arkadia. \\ Poznańskie sceny \\ dramatyczne 1918- \\ -1939), redaktorka \\ kilku książek. Zajmuje \\ się historią teatru \\ i dramatu antyczne- \\ go, międzywojennego \\ i współczesnego oraz \\ krytyką teatralną w jej \\ odsłonach historycz- \\ nej i praktycznej.
}


w kapeluszu, w białej koszuli z gorsem i krawatem trzyma ręce w kieszeniach, a pod każdym ramieniem - czaszka. Dziwny wyraz twarzy, ni to lekki uśmiech, ni ściągnięte rysy...

Dwie rzeczy komunikuje ten układ, na pierwszy rzut oka osobliwy, na drugi zaś odkrywający swoje staranne przemyślenie, będący zarazem zagadką (podsuwającą możliwe rozwiązania) i niepokojącym wabikiem. Fascynująca i przerażająca czaszka, umieszczona została pośrodku okładki trochę jak wskazanie obiektu badań (tak, będziemy się w tej książce zajmować trupami, szczątkami i kośćmi), a trochę jak ostrzeżenie, że propozycja będzie wywrotowa (tak, zwykle nie obchodzimy się z czaszkami w ten sposób, ale może właśnie warto umieścić je w niespodziewanej pozycji, by uzyskać nową perspektywę, albo dostrzec, że historyczne resztki niekoniecznie spoczywają wyłącznie w grobach, a źródła wiedzy o przeszłości mogą kryć się w niespodziewanych miejscach). Tytułowy neologizm sugeruje, że nie tylko my coś robimy ze szczątkami, ale że i ta czaszka "coś z nami robi” oraz że uprzednie byty, choć „już-nie-żywe”, wciąż coś komunikują bytom żywym i skłaniają je do działania. Ta okładka mówi też, że Dorota Sajewska stawia się tu w nieco innej pozycji niż w swoich poprzednich książkach, gdzie jej autorstwo nie było problematyzowane: tutaj właśnie jest, bo brak nazwiska na okładce rozumiem jako sygnał obustronnego oddziaływania - obiektu obdarzonego sprawstwem i piszącego podmiotu odpowiadającego na wołanie archiwum.

Ale to nie wszystkie okładkowe tajemnice: nie wiadomo bowiem od razu, kim mianowicie jest ów młodzieniec „pozujący z czaszkami”. Trzeba poszperać na stronie redakcyjnej - stamtąd (i tylko stamtąd, w książce bowiem to zdjęcie nie jest omawiane) czytelnik się dowie, że jest to fotografia Bertolta Brechta z roku 1917. Więc to Brecht w czwartym roku Wielkiej Wojny... Ale co to za czaszki? Gdzie i kiedy została zrobiona fotografia? Co robił w tym czasie, zaledwie dziewiętnastoletni? Jakie będą znaczenia tytułowego ,teatru Wielkiej Wojny" - bo skoro Brecht, to fraza "teatr wojny” z pewnością nie będzie jedynie metaforycznym wyrażeniem militarnym. Okładka wykorzystaniem detalu zdjęcia prezentowanego w całości dopiero na dalszych stronach sygnalizuje, co tu jest ważne: zoom na szczątki. Ale punctum fotografii jest zmienne, w zależności od tego, czy patrzymy na okładkę, czy na całość zdjęcia - pozornie pozostają nim czaszki obrazoburczo wciśnięte pod pachy, ale okazuje się, że wstrząsem jest tu odpowiedniość: nie sposób bowiem nie dostrzec takiej samej czaszki w twarzy Brechta. A więc nie symetria, nie odbicie, tylko bardziej wyrafinowana figura: idealny niemal trójkąt z wierzchołkiem wyznaczonym przez (jeszcze wówczas) „żywą" głowę. Kapelusz dopełnia 
groteskowego memento mori w wykonaniu Brechta, który jakby inscenizował sobie prywatnie Hamleta, tylko bardziej. Bo czaszki aż dwie. I raczej nie wiadomo, do kogo należały. Jeśli już, to role są tu rozdane odwrotnie: to Brecht pozuje na błazna, Yoricka, filozofa od śmierci.

W dodatku może grać wyłącznie filozofa-konceptualistę, ponieważ - choć właśnie mija rok 1917 - to nie jest zdjęcie wojenne. Brecht inscenizuje tu sytuację „ze śmiercią pod rękę" (choć czaszki absolutnie nie pełnią tu funkcji rekwizytów, są niepokojąco witalne...), ale przecież sam na wojnę nie poszedł i okopów ani walki nie doświadczył. To nie jest fotografia z żadnej pobitewnej ekshumacji. Frontowe historie nie staną się bezpośrednim udziałem Brechta. A więc to inscenizacja, gest, zaaranżowany obraz. Patrzcie, to ja ze śmiercią w czas wojny narodów. Dlaczego jednak właściwie nie powołano go do wojska, skoro głównie tacy chłopcy, jak on, masowo stawali się rekrutami? Autorka wyjaśnia ten biograficzny przypadek: bo ze względu na zły stan zdrowia (oraz, co możliwe, interwencję rodziny) uznany został za niezdolnego do służby czynnej. Pozostawiono możliwość ewentualnego powołania go do służby pomocniczej, co jednak się nie stało od razu. W czasie wojny Brecht zdał maturę, a potem studiował: medycynę, filozofię i teatrologię (właśnie ustanawianą jako dyscyplinę naukową, co dla książki Doroty Sajewskiej jest bardzo ważne) - i być może z racji studiów medycznych miał „dostęp” do czaszek widocznych na zdjęciu. Do wojska trafił - jak przypomina autorka - ostatecznie bardzo późno, dopiero 1 października 1918 roku, kiedy to skierowany został jako „siła medyczna” do augsburskiego szpitala wojskowego, w którym wszakże nie ratowano rannych w bitwach żołnierzy, ale leczono choroby zakaźne i weneryczne. Czyli Brecht wprawdzie „nie widział ciał żołnierzy zmasakrowanych przez bomby, granaty i szrapnele", ale jednak miał wówczas „kontakt z cierpieniem, bólem i śmiercią”, bo do jego obowiązków należało także „transportowanie trupów” (s. 126).

Niezwykłe rzeczy mówi więc to zdjęcie. Brecht fotografuje się z czaszkami wtedy, kiedy nie ma jeszcze bezpośredniej styczności ze śmiercią wojenną, z ciałami i szczątkami, gdy natomiast znajduje się wśród żołnierzy będących ofiarami wojny, niczego nie dokumentuje. Jednak wiele lat później komponuje - o czym pisze autorka - Kriegsfibel, wojenny album dokumentujący okropności wojny, wzorowany zapewne na podobnych albumach: Aby'ego Warburga Kriegskarthotek, a zwłaszcza Ernsta Friedricha Krieg dem Kriege! Wydaje się, że fotografia z czaszkami wyprzedzała czy jakoś zapowiadała fakt, że tematyka wojenna okazała się dla Brechta jedną z najważniejszych w późniejszej twórczości, by wspomnieć tylko Matkę Courage; dokumentowała rodzaj 
"gotowości" na obcowanie z tą problematyką. Zamieszczona na otwarciu książki (w dwóch ujęciach) mówi też coś o samej metodzie pracy autorki: żeby opowiedzieć Wielką Wojnę z perspektywy wielce nieoczywistej - czyli polskiej i kobiecej, jak czyni to Dorota Sajewska - trzeba „inaczej” dotknąć szczątków i samemu wystawić się na ich działanie. „Inaczej” Brechta polegało na tym, że w samym środku Wielkiej Wojny zajął wobec niej stanowisko „ironiczno-cyniczne”, które utrzymał na zawsze i które "stało się jego sygnaturą" (s. 126); mógł to zrobić właśnie dzięki temu, że nie uczestniczył w walkach bezpośrednio, a utrzymując dystans, przenikliwie zdiagnozował polityczne i narodowościowe podstawy wojennych rzezi. „Inaczej” Doroty Sajewskiej polega na obcowaniu z materiałami, które pozostawały w ukryciu jako możliwe, ale rzadko zauważane i wykorzystywane potencjalne źródło wiedzy; stanowiące niby materiał stricte archiwalny, jednak jakoś kłopotliwy. Pomijany. Nie tyle całkiem nieważny, co świadomie - w polskich narracjach - peryferyjny.Tak samo, jak z rozmysłem przyjęta perspektywa kobieca w opowieści o Wielkiej Wojnie. Sajewska wymija męskie mity niepodległościowe, legionowe, narodowe, za pomocą których ustanawiano narrację odrodzeniową i obracano wektor w stronę przyszłości (celowo przecież nie pytając zbyt dociekliwie, na czym została ona ufundowana), ale umieszcza swój punkt obserwacyjny wśród świadectw nieopowiedzianych, odrzuconych, nieoczywistych, może wręcz niechcianych, bo kogo w nowej Polsce obchodziło, co działo się w okopach obcych armii? W tych obcych armiach zaś, jak przypomina autorka, walczyły trzy miliony polskich żołnierzy, historie których (jako nie-legionistów) zostały w rodzimej pamięci kulturowej całkowicie zmarginalizowane. Podobnie, jak udział kobiet w tamtej wojnie: charakterystyczne, że przetrwał mit legionistów, zaś o legionistkach nikt pieśni nie śpiewał, choć przecież istniały.

Różnica polega też na tym, że czaszki Brechta zastąpiła Sajewska - zielnikiem. Jej postawa uwyraźnia się tu właśnie, w prologu książki, pozornie niemającym wiele wspólnego z głównym tematem Wielkiej Wojny. Zielnik Róży Luksemburg, odkryty w archiwum, okazał się obiektem obrosłym sensami i znaczeniami, pudełkiem zawierającym nie tylko zasuszone i sklasyfikowane rośliny, ostatnie dzieło rąk Róży, ale i konkretne biologiczne dane cząstki DNA zamordowanej rewolucjonistki, której ciała właściwie nigdy nie zidentyfikowano, a grób zniszczono. Zielnik, wykonany w więzieniu, w ostatnich latach życia, grupuje te dziwne rośliny, które potrafią wyrosnąć i przetrwać w skrajnie trudnych warunkach, w szczelinach muru, między płytami chodnika, w nędznej więziennej namiastce ogródka (co upodabnia ich 
egzystencję do życia więźniarki), albo dostały się tam przyniesione przez wiatr zza muru czy zostały podarowane przez osoby z zewnątrz przy okazji odwiedzin lub w listach (i wtedy dokumentują część życia więźniarce niedostępną, odebraną). Dorota Sajewska poddaje zielnik wielostronnej, precyzyjnej interpretacji: po pierwsze, znajduje w nim "szczególne świadectwo doświadczenia Wielkiej Wojny” (s. 28) i „zapis życia więziennego" (s. 29), ponieważ powstawał on właśnie wtedy, gdy Róża - dotąd intensywnie działająca, zaangażowana - została w latach największego wrzenia świata pozbawiona możliwości jakiegokolwiek czynnego wpływu na jego przyszłe losy. Pisała wówczas swoje ostatnie eseje polityczne i równolegle komponowała zielnik - pisma okazały się „ważne”, zielnik „nieważny”; sięgnięcie po zielnik (ujawnienie się zielnika?) okazuje się więc gestem wywrotowym, przekreślającym ustanowione hierarchie. Po drugie, właśnie w tym miejscu następuje w książce praktyczne uruchomienie jednego z kluczowych dla autorki pojęć ciała-archiwum, w przypadku herbarium ujętego jako „oparty na materialnych resztkach" zapis doświadczenia izolacji, skłaniającego jednak więźniarkę do osobliwego zachowania: porzucenia antropocentryzmu na rzecz szerszego spojrzenia na świat żywych istnień, nie-ludzkich towarzyszy zrównanych z człowiekiem w swojej podmiotowości - o czym wspomina w listach i pismach rewolucyjnych. Po trzecie wreszcie, kiedy po dziesiątkach lat podano w wątpliwość, czy ciało pochowane w 1919 roku było rzeczywiście ciałem Róży Luksemburg, zielnik został wykorzystany jako ostatni rezerwuar jej obecności, jako zbiór biologicznych danych: wprawdzie nie udało się wyodrębnić ani odcisków palców, ani cząstek DNA, niemniej taka próba została podjęta - i wówczas zielnik stał się zupełnie nowym rodzajem "dokumentu" oferującym pomoc przy rekonstrukcji życia pośmiertnego. Te materialne resztki (a w pewnym sensie rośliny i Róża stopiły się tu w jedną „organiczną resztkę" ciała-archiwum) pozwalają, jak pisze autorka, ,na wyłonienie sensu i ukazanie pełni egzystencji ludzkiej” (s. 22), pozostając jednocześnie „metaobrazem biografii politycznej Róży Luksemburg". Oraz przykładem tego - po czwarte - jak działać może tytułowy nekroperformans i w jakiej sytuacji się uaktywnia: gdy następuje jakiś kryzys w kwestii trupa/ciała, np. niepewność co do identyfikacji (bo w bezkryzysowym przebiegu przemiany trupa w ciało - które staje się miejscem lokowania znaczeń symbolicznych - mamy zawsze do czynienia z pełną identyfikacją i pochówkiem, co przenikliwie w swojej nekrografii Mickiewicza opisał Stanisław Rosiek), szczególnego znaczenia nabierają wszelkie materialne resztki, przez które oddziałuje nieobecne ciało, oraz to, co żywi czynią z owymi resztkami. Nekroperformans - daje autorka 
jedną z wielu możliwych interpretacji tego niejednoznacznego przecież, ale świetnie działającego w jej książce pojęcia - „dokumentuje zatem to, co w pisaniu historii umarłych zostało nieuświadomione, przeoczone lub zepchnięte na margines życia politycznego i dyskursu historycznego" (s. 38).Zrozumiałe więc, że Róża Luksemburg - w postaci zielnika - otwiera tę książkę: staje się znakomitą reprezentantką figur i zjawisk kłopotliwych w polskiej narracji o Wielkiej Wojnie. Żydówka, Polka, Niemka, kobieta, komunistka, nieantropocentrycznie myśląca, niezainteresowana kampanią narodowościową i niepodległościową tylko walką klas rewolucjonistka, która została najpierw uwięziona, potem zamordowana, a na końcu pośmiertnie unicestwiona (nawet podwójnie, łącznie $\mathrm{z}$ dewastacją grobu...). Jest tak strasznie uciążliwa i niewygodna, nie pasuje właściwie nigdzie, a już na pewno nie mieści się w polskiej historii odrodzeniowej... i właśnie dlatego mogła stać się inspiracją dla intensywnych praktyk „rekonstrukcyjnych” dokonywanych przez Dorotę Sajewską na podobnie nieoczywistych szczątkach (i dostarczyć pozwolenia na ich nekrotyczne działanie). Figura zielnika wreszcie - po piąte - przemyślnie wprowadza pytania o role płciowe. Komponowanie zasuszonych roślin wydaje się czynnością stereotypowo kobiecą, bliską „układaniu bukietów” czy „zajmowania się ogródkiem” (jak u Mickiewicza: Zosia - do podlewania ogródka, mężczyźni z Wojskim - do lasu na polowanie), tymczasem autorka podkreśla, że zainteresowania botaniczne Róży Luksemburg mogły być inspirowane podobnymi badaniami Goethego, a jej zbiory i ich precyzyjne opisy pogłębiały pasje przyrodnicze całkiem podobne do tych, które - w tym samym czasie - kultywował Stefan Żeromski. Herbarium Róży więcej miało wspólnego z rzetelną wiedzą, głębokim przemyśleniem swojego miejsca w świecie przyrody (ale i w świecie polityki: opisy roślin, jak zauważa autorka, wydają się czasem znaczącym komentarzem do wojenno-więziennej egzystencji) niż jakimkolwiek konwencjonalnym kobiecym gestem. Zielnik metaforycznie łączy się też z (zabronionym lub przeciwnie, przymusowym) udziałem w bezpośredniej walce, podczas wojny najoczywiściej zależnym od płci, o czym w kolejnych rozdziałach szczegółowo pisze Dorota Sajewska. Kobiety - decyzją Piłsudskiego - nie mogły być żołnierkami w legionach; te najbardziej zdeterminowane pozostawały więc w nich nielegalnie, pod męskimi pseudonimami (i na męskich papierach), czasem wręcz w męskim przebraniu (realizując w pewnym stopniu męski fantazmat i działając właściwie dzięki utrzymywanemu w tajemnicy przyzwoleniu), inne - mimo pragnienia walki - nie zostały dopuszczone na front i pełniły tradycyjne funkcje sanitariuszek lub pracowały w "jednostkach pomocniczych". 
Ambiwalencja związana z rozdziałem płciowych ról kulturowych ujawniła się także w teatrach wojennych, i to w obie strony: grających męskie role aktorek z Teatru Ochotniczej Legii Kobiet lub - co okazało się znacznie bardziej dotkliwe, łamiące tabu niejednoznaczności płci, a bodaj podczas Wielkiej Wojny wdrożone po raz pierwszy - żołnierzy grających role kobiece. Sajewska relacjonuje w książce ciekawe zbiory fotografii i świadectw, wystawy i antologie tekstów przygotowane przez badaczki niemieckie zainteresowane tym aspektem teatru Wielkiej Wojny, z żalem dodając: „trudno sobie wyobrazić, by w jakimkolwiek muzeum w Polsce miała miejsce wystawa wraz z towarzyszącą jej debatą historyczno-kulturową na temat legionistów, którzy w wolnym od bitew czasie - za pomocą szminki, kostiumu, ale także odpowiedniego treningu głosu i ruchu - poddawali swoje ciała transformacji w kobietę" (s. 228-229). Sama więc wypełnia tę lukę, omawiając kilka rodzimych teatrów legionowych i jenieckich, z jednej strony pokazując, jak przedstawienia te działały niczym „wojenny karnawal” z odpowiednią dawką wulgarnego „leguńskiego humoru”, z drugiej jednak - jak przewrotnie „rozsadzały wojenny dyskurs patriotyczno-narodowy”, zamiast „imitacji mężczyzny-wojownika” ukazując znacznie bardziej cenioną w teatrze „imitację powabnej kobiety" (s. 233, 228). Zielnik Róży Luksemburg w nieoczywisty sposób pracuje w całej książce, odnosząc się do kolejno wprowadzanych w niej tematów - co jednak widać w pełni dopiero po lekturze; to oznacza też konieczność (lub zaproszenie do) czytelniczych nawrotów, kołowania, przeskoków. Ta książka też jest trochę jak zielnik: można oglądać każdą roślinę osobno, w dowolnej kolejności, ale wiadomo, że dopiero razem tworzą precyzyjnie skomponowany układ, choć nie jest on ani skończony, ani pełny.

Dostrzegam więc delikatną ironię autorki w posłużeniu się fotografią Brechta na okładce i stronie tytułowej, bo jakkolwiek jego pacyfizm, antywojenne dzieła i rewolucyjny potencjał dramatów służą tu także za przykłady postaw wobec Wielkiej Wojny, to przecież nie o taki jej wizerunek chodzi. Dorota Sajewska gra z obrazem czaszek i Brechta, bo wobec problematyki jej książki wykorzystana fotografia zarazem komunikuje, czego w książce nie będzie, jak i co się w niej znajdzie. Nie ma tu zatem jej dotychczasowych głównych męskich aktorów, uwaga zaś skierowana jest ku przed/podmiotom słabym (i często martwym), w których jednak lokuje się główna myśl Nekroperformansu: że owa materialna resztka - nazywana "ciało-archiwum" - nie stanowi „biernego obiektu rekonstrukcji historycznej”, lecz aktywny, podlegający zmianom obiekt dający „impuls do intensyfikacji procesu poznawczego" (s. 71) prowadzonego w szerokiej ramie historycznokulturowej. 
Charakterystyczne, że na rewersie wyzywającej fotografii Brechta znalazła się w książce właśnie skromna, łatwa do przeoczenia fotografia podniszczonego pudełka, w którym przechowywano zielnik Róży Luksemburg... A więc w istocie - dwa portrety, dwie reprezentacje, obie nieoczywiste, obie w nowych funkcjach. Brecht występuje tu raczej jako patron metody montażu i dowód na stałe podskórne pulsowanie problemów Wielkiej Wojny, dziś przysłoniętej masakrą II wojny światowej. Róża Luksemburg zaś jako wywrotowy podmiot kobiecy, a jej zielnik jako nieoczywista - bo zarazem abiektalna i fascynująca, marginalna i centralna, dokumentarna i organiczna - intensywnie działająca resztka.

Dorota Sajewska stawia pytania o nieczęsto obecne w polskich wyobrażeniach doświadczenia Wielkiej Wojny pozostające poza polem upamiętnienia, a nawet poza polem widzialności - te, które można z owych resztek wydobyć i będących podobnie, jak one, doświadczeniami poszarpanymi, niedającymi się ułożyć w spójne całostki, niepozwalającymi się nawet wyrazić, czyli ująć w linearne narracje (te zostały zarezerwowane dla opowieści zwycięskich). Szuka więc w archiwum różnorakich „zgniecionych" świadectw i za ich pomocą tworzy nowe archiwum, wybitnie niekanoniczne, dające jednak mocny głos przywołanym bohaterom; mocny - bo sytuujący ich w doskonale skonstruowanej, pełnej opowieści, jakby będącej zadośćuczynieniem za wcześniejsze kłopotliwe usunięcie; mocny - bo choć książka ma wyraźnie celowo nieciągłą budowę, to każdy z omawianych problemów i bohaterów dostaje tu swoją osobną porcję intensywnej uwagi; mocny - bo wyraziście ustanawiający nowy rodzaj opowieści o historii. Wreszcie, co wydaje mi się najważniejsze, mocny - paradoksalnie - mocą słabości, która zmienia wektor.

Dlatego, że sytuacja w Nekroperformansie jest taka oto, że „słaby” wobec Wielkiej Wojny podmiot kobiecy (autorka) znajduje sposób, by tamte „słabe" (wyparte) wydarzenia ująć w historii alternatywnej, ufundowanej na przywróceniu/nadaniu "słabemu” dokumentowi (ciału) pozycji nie tylko ważnej, ale i aktywnej. Oznacza to zaakceptowanie (ale najpierw: odkrycie) wszystkiego tego, co się z ciałem-archiwum w kulturze wydarza, a więc nieciągłości, występowania w postaci formy zużytej i wielokrotnie przetwarzanej (także medialnie), ułomnej i tak bardzo podatnej na manipulacje (casus: Wyspiański). Paradoksalnie „słaby” okazał się także polski wizerunek I wojny, ponieważ utrwalił się jako jednostronny, pozbawiony niuansów złej pamięci obraz źródeł narodowego odrodzenia, z Legionami na pierwszym planie. Choć falami, głównie w momentach rocznicowych, wracają dyskusje o Wielkiej Wojnie i założycielskich problemach nowoczesnej „Europy 
państw", to w Polskiej kulturze (najpierw zapewne zdecydowały tu względy polityczne i niepodległościowe przymusy) niewiele było prób - zwłaszcza po II wojnie i Zagładzie jako bezpośrednich traumatycznych doświadczeniach - powrotu do przemyśleń pierwszowojennych i tamtych ofiar. Jak stwierdził Ryszard Kaczmarek (w jedynej książce historycznej o Polakach w armii kajzera), a za nim autorka: „w polskiej pamięci kulturowej Polak w niemieckim mundurze i pikielhaubie nie przetrwał ani jako sprawca, ani jako ofiara Wielkiej Wojny. Zniknął po prostu, zapomniany" (s. 178). Dorota Sajewska na nowo problematyzuje jego ślady, nie tylko w kulturze polskiej, ale w ponadnarodowym spotkaniu i mediacjach kultur polskiej i niemieckiej, zarówno tuż przed, w trakcie, jak i po Wielkiej Wojnie. W kulturze niemieckiej (i szerzej: zachodniej) sprawa wojny została jednak wielorako upamiętniona, i to krytycznie: katastrofa, jaka wówczas się wydarzyła, katastrofa o wymiarze dotąd niesłychanym, masowym, potwornym, została przerobiona w setkach dzieł. W kulturze polskiej tamta wojna była (i jest) opowiadana w perspektywie odzyskania państwowości, a więc pozostaje nieopowiedziana. "Szczątki Polaka w pikielhaubie” w wielorakich przetworzeniach - dawniejszych (Wyspiański, Witkacy) i całkiem współczesnych (Kozyra, Żmijewski) - działają w książce Doroty Sajewskiej jednak nie w sprawie przywrócenia niechcianej pamięci, ale jak się wydaje, w kwestii bardziej dzisiaj istotnej: pokazują mianowicie, jak pracuje zakazany, wyparty wizerunek umęczonego, poranionego ciała. Jeśli zostaje odrzucony i usunięty z pola widzialności, to jego brak działa znieczulająco i sprzyja raczej wytwarzaniu "fantazmatów bohaterów" i narracji heroicznej, zamiast ostrzegać przed wojną. Łatwo też wtedy o zamianę konkretnych ofiar w ofiarnicze ciało zbiorowe, które wprawdzie podlega grozie wielkich liczb, ale nie wpływa na wyobraźnię i nie da się przekształcić w doświadczenie. Wojna nie będzie więc "polem trupów” i tysiącami straumatyzowanych inwalidów; będzie okazją do ochoczego przebrania się w mundur i skandowania patriotycznych haseł.

Poza tym więc, że jest niezwykle nośnym terminem, nekroperformans objawił się w książce Doroty Sajewskiej jako mocne narzędzie do praktycznego sprawdzania, jak działa (na ciało, poprzez ciało) przeszłość i dlaczego właśnie tak. Narzędzie do ustanowienia nowego wymiaru dokumentu (ciała) w badaniu jego znaczenia i sprawczości. Zwracające też uwagę na (ciało) badacza, którego relacje z badanym obiektem stają się wielostronne i skomplikowane, a na pewno niehierarchiczne. I wreszcie, pozwalające na negocjowanie i uzgadnianie pojęć i ustaleń wielu dyscyplin, bo choć teatr i teatralizacja oferują tu podstawową (ale bywa, że zaskakującą) perspektywę medialną, 
to wybitnie ważny wydaje się ów przepływ między dziełami, zjawiskami, bohaterami i problemami, który - dzięki nowo ustanowionej kategorii ciała- archiwum - łączy chorobę afektywną dwubiegunową Witkacego z Powrotem Odysa. I tak naprawdę może pomóc w debacie w sprawie życia, a nie śmierci.

\section{Abstract}

\section{Ewa Guderian-Czaplińska}

ADAM MICKIEWICZ UNIVERSITY (POZNAŃ)

Experiencing the Past: Dorota Sajewska's Necroperformance

Review: Dorota Sajewska, Necroperformance: The Cultural Reconstruction of Theatre [Nekroperformans: Kulturowa rekonstrukcja teatru Wielkiej Wojny] (Warsaw: Instytut Teatralny im. Zbigniewa Raszewskiego, 2016)

\section{Keywords}

The Great War, Rosa Luxemburg, Bertolt Brecht, women and war, body-archive 